\title{
Implementation of Lean Six Sigma Method in High-Rise Residential Building Projects
}

\author{
Syafrimaini, Albert Eddy Husin* \\ Department of Civil Engineering, Mercu Buana University, Kembangan, 11650, Jakarta, Indonesia
}

Received March 23, 2021; Revised May 11, 2021; Accepted June 6, 2021

\section{Cite This Paper in the following Citation Styles}

(a): [1] Syafrimaini, Albert Eddy Husin, "Implementation of Lean Six Sigma Method in High-Rise Residential Building Projects," Civil Engineering and Architecture, Vol. 9, No. 4, pp. 1228-1236, 2021. DOI: 10.13189/cea.2021.090424.

(b): Syafrimaini, Albert Eddy Husin (2021). Implementation of Lean Six Sigma Method in High-Rise Residential Building Projects. Civil Engineering and Architecture, 9(4), 1228-1236. DOI: 10.13189/cea.2021.090424.

Copyright $(2021$ by authors, all rights reserved. Authors agree that this article remains permanently open access under the terms of the Creative Commons Attribution License 4.0 International License

\begin{abstract}
Fueled by the growth of residential needs, high rise building projects has become a major contributing segment that increases the competition in the world of construction project services [1]. In the implementation of high-rise building construction projects, scheduling and good quality control plays a very important role in the timeliness, cost, and quality of the overall project completion. Project delays often occur in the construction project implementation process. It results in poor quality that is not in accordance with the technical specifications. In the end, it causes loss to a project [2]. Project delays may occur because of internal factors, external factors, weather disturbances, changes in images, etc. Quality failures are usually caused by poor communication between parties in a project. Project development must fulfill the 3 most important things, namely cost, quality, and time. [3]. Cost overrun is one of the issues confronting the construction industry. Most of the construction projects in Malaysia have experienced a cost overrun of 5 to $10 \%$ of the total contract [4]. To control the cost, quality, and time, the researchers used the Lean Six Sigma method. Lean Six Sigma is a combination of lean and six sigma which can be defined as a business philosophy, systemic and systematic approach to identifying and eliminating waste or activities that are not value-added through the continuous increase in productivity to reach level Six Sigma, and consists of 5 stages of improvement commonly called DMAIC consisting of Define, Measure, Analyze, Improve, and Control [5]. This research focuses on basement construction, especially bore pile secant pile and excavation work. By applying the Lean Six Sigma method, we can get a cost efficiency of $6,85 \%$ and a time efficiency
\end{abstract}

of 9,60\%. Therefore, this research is very useful.

Keywords Lean Six Sigma, Cost, Basement

\section{Preliminary}

\subsection{Introduction}

In the implementation of high-rise building construction projects, scheduling and good quality control play a very important role in punctuality, cost, and quality of the overall project completion. Project delays often occur in the construction project implementation process. It results in poor quality that is not following the technical specifications. In the end, it causes loss to a project. There are a few factors as to why project delays happen, such as internal factors, external factors, weather disturbances, changes in images. Failure factors for the quality of a project can be seen in Figure 1. Below, where the biggest cause of quality failure is poor communication between related parties in a project, which is about $57 \%$. Project management is considered good if these 3 goals are achieved. In terms of efficiency, what is meant is the appropriate use of resources and selection of sub-activities. This includes amount, types, the use of other effective sources, the use of resources and activities covering quality, cost, and time. The factors that influence the success of a project are project factors, project procedures, project management, human factors, and external environmental factor [7]. Project development must fulfill the 3 most important things, namely cost, quality, and 
time. To control time, quality, and work value that control waste, Lean Six Sigma is a combination of lean and six Sigma. This can also be defined as a business philosophy, systemic and systematic approach to identifying and eliminating non-value activities through continuous improvement of productivity. The ultimate goal is to reach the Six Sigma level (six sigma).

\subsection{Research Questions}

The research questions formulated are as follow:

1. How to analyze the implementation of Lean Six Sigma on the bored pile, secant pile, and excavation work of a 5 -floor basement project?

2. How much is the cost-efficiency percentage obtained by implementing Lean Six Sigma in bored pile and excavation work?

3. How much is the time efficiency percentage obtained by applying Lean Six Sigma to bored pile and excavation work?

\subsection{Research Purposes}

The purposes of this research are:

1. To analyze the implementation of Lean Six Sigma on the bored pile, secant pile, and excavation work of a 5-floor basement project.

2. To analyze the cost efficiency percentage obtained by implementing Lean Six Sigma in bored pile and excavation work

3. To analyze the time efficiency percentage obtained by implementing Lean Six Sigma in bored pile and excavation work.

\subsection{Benefits of Research}

The benefits of this research are

1. To develop and apply the Lean Six Sigma method resulting in a more cost-efficient project.

2. To increase readers' insight into the use of Lean Six Sigma.

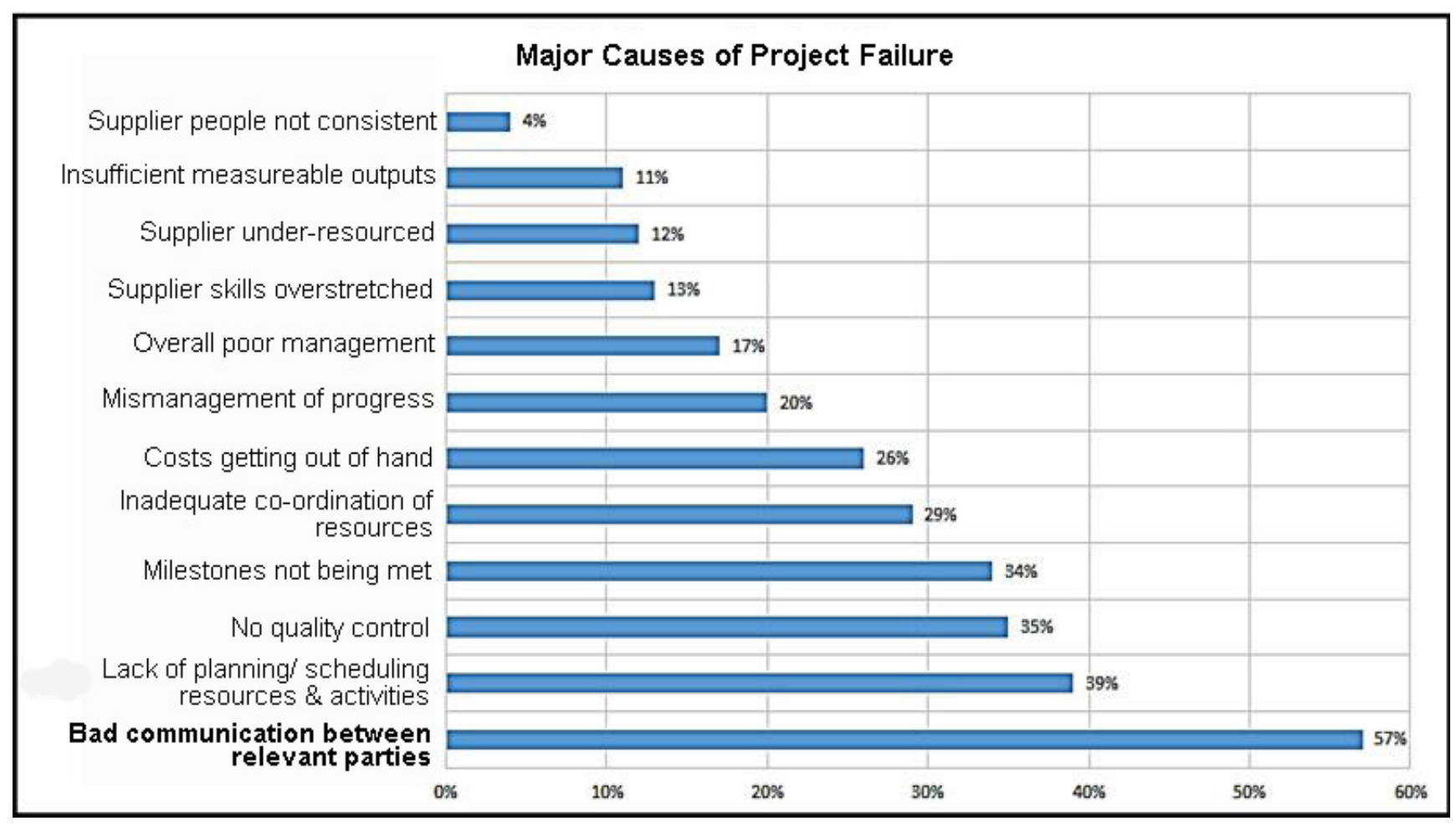

Figure 1. Failure of a Project [6] 


\section{Literature Review}

a) Definition of Lean

According to [8] lean is a systematic approach to defining and eliminating waste or non-value adding activities through continuous improvement radically. This can be achieved by keeping a flow of products (material, work-in-process, output) and information using a Pull system from internal and external to achieve excellence.

\section{b) Definition Six Sigma}

The six sigma method is a process that applies statistical tools and techniques to reduce defects until it is defined as no more than 3.4 defects out of one million opportunities to achieve total customer satisfaction [9]. Six sigma provides added value to customers and stakeholders by focusing on improving the quality and productivity of the company [10].

In figure 2, the Six Sigma cycle uses statistical tools to identify several vital factors. The most determining factors for improving process quality and generating profit consist of 5 stages called DMAIC (define, measure, analyze, improve, control), as shown below [5]:

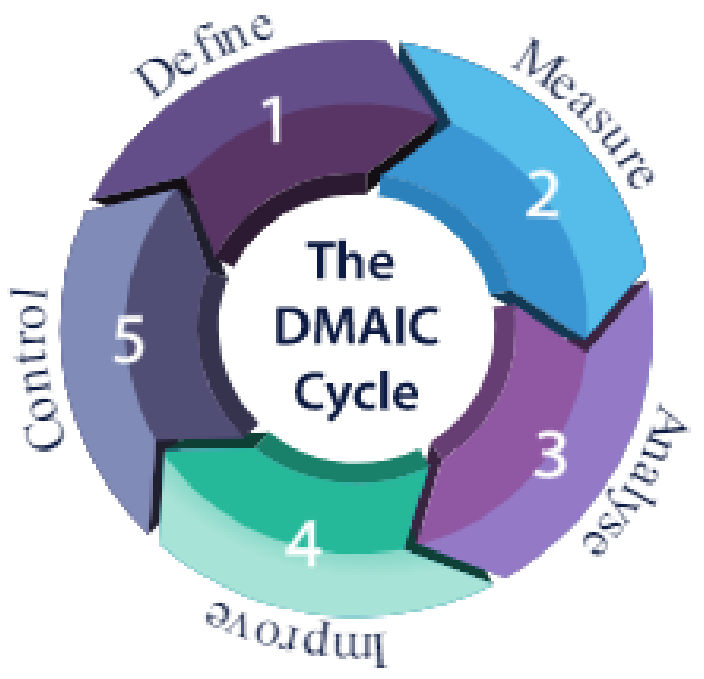

Figure 2. Cycle Six Sigma ${ }^{[11]}$

\subsection{Waste}

In his book "Lean Six Sigma" [10] explains that waste is any work activity that does not provide added value in the transformation process from input to output through the value stream. [12] Besides, that Lean construction is a method used to design a product that minimizes waste, shortens its duration [13] defines waste or waste as "any inefficiency which results in the use of a greater quantity of equipment, materials, labor or capital than is deemed necessary in the production of a building". A simple way of defining waste is that which can be eliminated without reducing customer value. It could be activities, resources, rules, etc.

According to [14] Toyota production system, 7 types of waste that often occur in the production process which is often shortened to "TIM-WOOD":
- Waste of Transportation
- Waste of Inventory
- Waste of Motion
- Waste of Waiting
- Waste of Over Processing
- Waste of Overproduction
- Waste of Defect

\subsection{Definition of Basement}

Basement is a vertical downward development that creates an underground space that is a part of the building. At present, basement construction is increasingly popular and is developing as a solution to optimize land use such as parking lots - and other businesses besides being used as utility space. The method used in basement work is the Top-Down method. The basement structure work is carried out simultaneously with excavation. The order of finishing the beams and floor plates starts from the top to the bottom. During the implementation process, the plate and beam structure is supported by a pillar structure (king post) that is installed together with the bored pile.

Bored Pile

A bored pile foundation is a pile foundation which installation is done by drilling the ground first [15].

\section{- $\quad$ Secant Pile}

Secant Pile is an in-situ type Soil Retaining Wall which is used in narrow areas because this method does not require water. According to [16] secant pile in its implementation requires more concrete material and reinforcement and requires a longer time than concrete sheet pile

\section{- Excavation}

Excavation is one of the stages in earthworks [17].

\section{- Excavation Equipment}

According to the Earthwork \& Soil Compaction Construction Equipment Handbook, Excavation Equipment (Excavator), namely; Intermittent and Trencher (Multibucket). Intermittent consists of Power Transm (Mechanic and Hydraulic) and Attachments (Loaders, Excavators, Grips. Jaws). While Trencher (Multi bucket) consists of Rotary and Bucket-line (Ladder). Figure 3 is earthwork heavy equipment: 


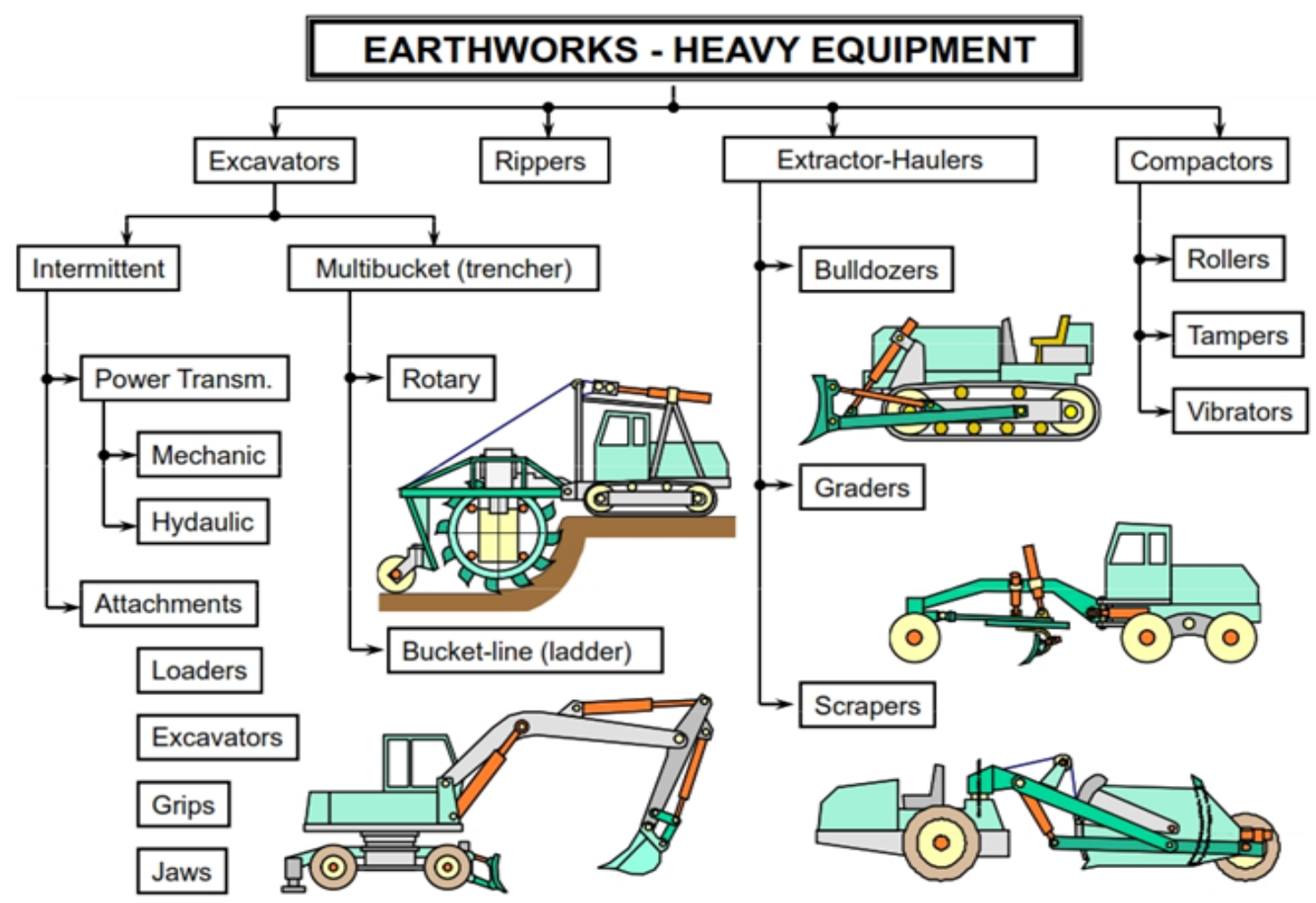

Figure 3. Earthwork Heavy Equipment [18]

\section{Research Methodology}

This research is descriptive. Descriptive analysis is an analytical method used to obtain the average value, minimum value, maximum value, and median value of each variable. From the average value later, it is expected that a temporary conclusion will be drawn from the research questions in general. The following are the research steps:

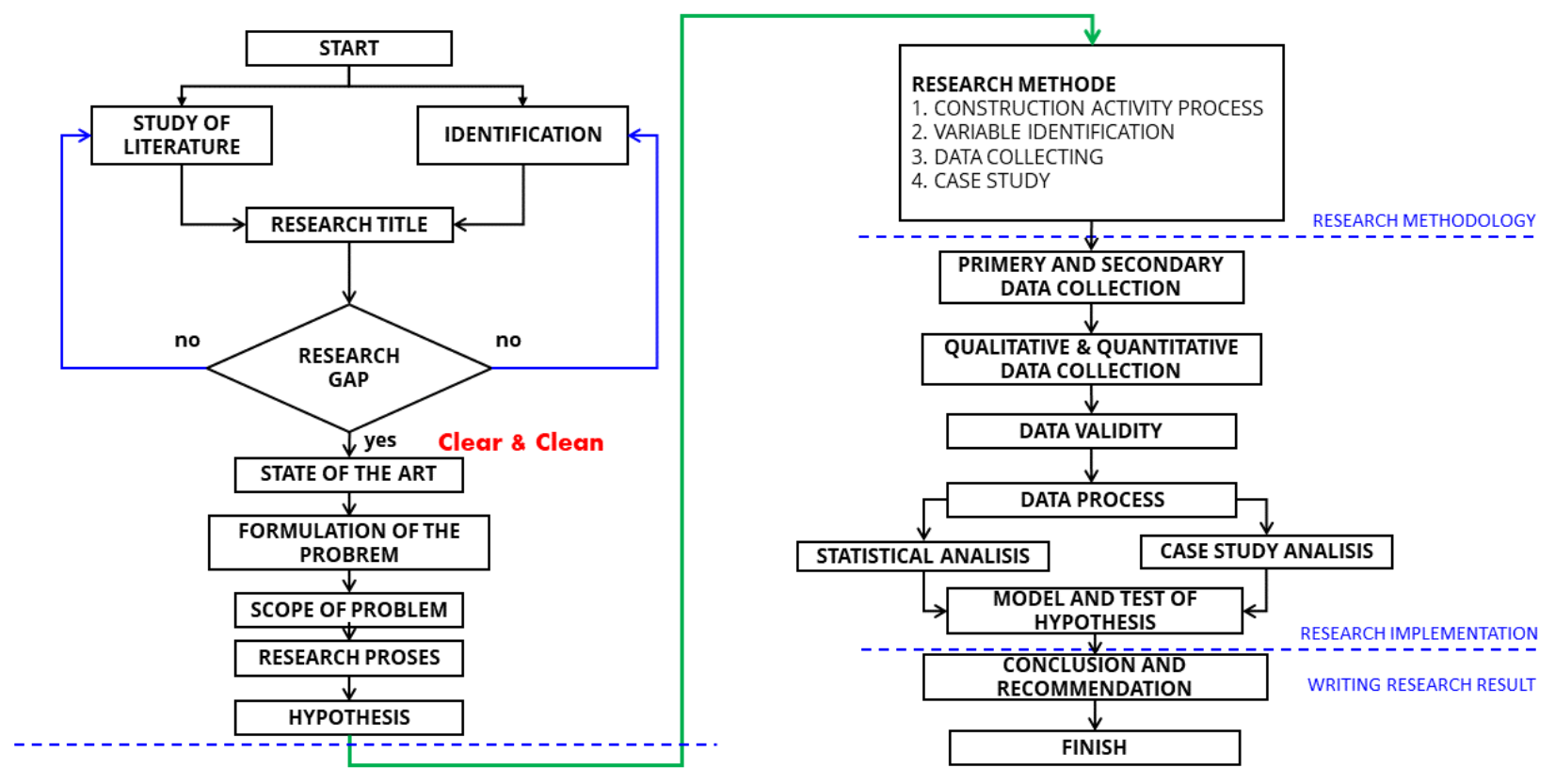

Figure 4. Research Flow Chart [19] 
In this study using Six Sigma, the stages of implementation consist of Define, Measure, Analysis, Improve, Control. Here's the explanation:

\section{a) Define}

This stage is to understand and identify the problems in detail. The main purpose of this stage is to identify the problem correctly, up to the description of the problem's cause

\section{b) Measure}

The measuring stage is the second stage in the DMAIC methodology, where at this stage the measurement and identification of potential sources of the problem that occur in a process will be carried out. Actual process capability will be quantified at the source of potential non-conformities.

\section{c) Analysis}

The analysis phase at DMAIC focuses on identifying the causes of the problem that affect company productivity.

\section{d) Improve}

After the root of the problem is understood, the analysis is carried out by collecting ideas to solve the problems, which then improves the performance of measuring variables that can solve it.

\section{e) Control}

The control phase is a stage in the form of supervision efforts in maintaining all improvements that have been made. This effort is also expected to be able to implement the suggestions from the results of the improvement at a certain time. This is done so that the resulting impact will have a good effect on discrepancies that occur in business processes.

\section{Results and Discussion}

This study uses SPSS as a data processing tool to obtain the factors that affect costs. The following factors that affect costs are shown below:

Table 1. Factors affecting costs

\begin{tabular}{|c|c|c|c|}
\hline Item & \multicolumn{2}{|r|}{ Sub Factor } & Reference \\
\hline \multirow{10}{*}{$\begin{array}{l}\text { Cost } \\
(\mathrm{Y} 1)\end{array}$} & Y1.1 & $\begin{array}{l}\text { Bad Design and Delays in } \\
\text { Design }\end{array}$ & $\begin{array}{l}\text { Samarghandi, H. } \\
{[20]}\end{array}$ \\
\hline & Y1.2 & $\begin{array}{c}\text { Unrealistic contract } \\
\text { duration and terms imposed }\end{array}$ & Samarghandi, H., \\
\hline & Y1.3 & Lack of experience & Samarghandi, H., \\
\hline & Y1.4 & $\begin{array}{c}\text { Late delivery of materials } \\
\text { and equipment }\end{array}$ & Samarghandi, H., \\
\hline & Y1.5 & $\begin{array}{l}\text { The relationship between } \\
\text { management and labor }\end{array}$ & Samarghandi, H., \\
\hline & Y1.6 & $\begin{array}{l}\text { Delays Preparation and } \\
\text { approval of drawings }\end{array}$ & Samarghandi, H., \\
\hline & Y1.7 & $\begin{array}{l}\text { Inadequate planning and } \\
\text { scheduling }\end{array}$ & Samarghandi, H., \\
\hline & Y1.8 & $\begin{array}{l}\text { Poor site management and } \\
\text { supervision }\end{array}$ & Samarghandi, H., \\
\hline & Y1.9 & Error during construction & Samarghandi, H., \\
\hline & Y1.10 & $\begin{array}{l}\text { Changes to specifications } \\
\text { and material types }\end{array}$ & Samarghandi, H., \\
\hline
\end{tabular}

From these cost factors, it is found that the 3 most dominant cost factors are poor design and delays in design (YI.1), inadequate planning and scheduling (YI.7), and errors during construction (YI.9).

The following is the implementation of lean six sigma:

\section{a) Define}

This stage is the initial stage of the DMAIC cycle. At this stage, the problems found are formulated and which activities are included in the value-added and non-value-added activities. Then, the variables causing project delays from the literature study were collected as many as 50 variables. The result of this Define stage is to obtain the relevant delay variables in the PT. X

\section{Preliminary Stage Data Collection}

The preliminary stage questionnaire aims to validate the variables causing delays in the PT.X at the construction implementation stage obtained from several literature studies. Experts are asked to fill out the questionnaire given in the available column with relevant/irrelevant answers, the results of this questionnaire are also used as a basis for narrowing down the type variables in the case study so that the results of the main questionnaire become more accurate, and in the future, it will be easier to determine in this section, which improvements will be made to avoid delay. The profile of the respondents from the initial stage of the questionnaire was people who were experienced and played an active role in the PT. X. The results of data collection in the first stage questionnaire addressed to the expert concluded that there were 50 variables stated as relevant as variables causing changes in project costs at the PT. X.

\section{b) Measure}

The measurement phase in Lean Six Sigma is related to the collection of the most dominant delay variables based on the significance level of the variables as measured in time units. After finding which variable has the highest significance, a Pareto diagram is shown to determine the mismatch based on the causes of project delay. The results of data collection on the main stage questionnaire addressed to experts concluded that there were 60 variables, with 3 variables being stated as the variables causing changes in project costs at the PT. X.

\section{c) Analyze}

Based on the results at the Measure stage, there were 3 most dominant variables, namely poor design and delays in design (Y1.1), inadequate planning and scheduling (Y1.7), and errors during construction (Y1.9).

1. In the existing excavation work can be seen in the table below:

Table 2 is the planned or existing work carried out at the beginning of the planning. The excavation volume is $95,625 \mathrm{M} 3$, and the number of days planned is 110 days, 
with a bucket excavator capacity used at $45 \mathrm{~m}^{3} /$ hour and a dump truck with a capacity of $20 \mathrm{~m} 3 / \mathrm{r}$ respectively. Each dump truck uses 2 trips/day, and so the total plan costs USD 369,874.50. Furthermore, calculations with alternatives are carried out, and the results are as shown in the table below.

In table 3 , an alternative is a plan by calculating the bucket excavator capacity of $67.5 \mathrm{M} 3 /$ hour where the excavation volume remains at 95,625 M3. With the number of excavator units adjusted to the volume of excavation work, the need for dump trucks is according to excavator productivity, the calculation results obtained the value of USD $330,271.95$, - so there is efficiency.

$$
\begin{aligned}
& =\text { USD 369,874.50 - USD 330,271.95 } \\
& =\text { USD 39,602.55, (10,71\%) }
\end{aligned}
$$

From the implementation time data result with a comparison between the initial time (existing) and the time after implementation, the time efficiency is reduced from 103 days to 100 days. In conclusion, 3 days are efficient $(2.91 \%)$

\section{In Bored Pile and Secant Pile jobs}

From table 4 with an increase in time accuracy, the productivity increases which will indirectly affect the efficiency of Time and Cost. In increased productivity, the delay and time waste in a project can be reduced, so that all costs will be efficient. This can be seen in the table below:

From table 5, it can be inferred that from the results of implementing Lean Six Sigma on bored pile work, secant pile can produce time efficiency of $12.51 \%$ and cost-efficiency of $6.68 \%$ or USD 541.294

From table 6 it can be concluded that the total time efficiency of the results of implementing Lean Six Sigma on drill pile work, cutting piles can produce a time efficiency of $9.60 \%$, and from table 7 it can be seen that the total cost efficiency value is $6.85 \%$.

\begin{tabular}{|c|c|c|c|c|c|c|c|c|c|}
\hline \multirow[b]{2}{*}{ Stage } & \multirow{2}{*}{$\begin{array}{l}\text { VOL / } \\
\text { /M3 }\end{array}$} & \multicolumn{4}{|c|}{ EXCAVATOR( EXC ) } & \multicolumn{4}{|c|}{ DUMP TRUCK ( DT ) } \\
\hline & & EXC & Days & $\begin{array}{c}\text { Rental/Days } \\
\text { (USD) }\end{array}$ & $\begin{array}{c}\text { Rental Exc } \\
\text { (USD) }\end{array}$ & DT & Days & $\begin{array}{c}\text { Rental/Days } \\
\text { (USD) }\end{array}$ & $\begin{array}{c}\text { Rental DT } \\
\text { (USD }\end{array}$ \\
\hline 1 & 8,750 & 3 & 4 & 120.75 & $1,449.00$ & 10 & 4 & 124.20 & $4,968.00$ \\
\hline 2 & 2,750 & 3 & 7 & 120.75 & $2,535.75$ & 10 & 7 & 124.20 & $8,694.00$ \\
\hline 3 & 625 & 3 & 4 & 120.75 & $1,449.00$ & 10 & 4 & 124.20 & $4,968.00$ \\
\hline 4 & 17,500 & 3 & 10 & 120.75 & $3,622.50$ & 50 & 10 & 124.20 & $62,100.00$ \\
\hline 5 & 2,750 & 3 & 7 & 120.75 & $2,535.75$ & 10 & 7 & 124.20 & $8,694.00$ \\
\hline 6 & 625 & 3 & 5 & 120.75 & $1,811.25$ & 10 & 5 & 124.20 & $6,210.00$ \\
\hline 7 & 17,500 & 3 & 10 & 120.75 & $3,622.50$ & 50 & 10 & 124.20 & $62,100.00$ \\
\hline 8 & 2,750 & 3 & 7 & 120.75 & $2,535.75$ & 10 & 7 & 124.20 & $8,694.00$ \\
\hline 9 & 625 & 4 & 5 & 120.75 & $2,415.00$ & 10 & 5 & 124.20 & $6,210.00$ \\
\hline 10 & 17,500 & 4 & 10 & 120.75 & $4,830.00$ & 50 & 10 & 124.20 & $62,100.00$ \\
\hline 11 & 2,750 & 4 & 7 & 120.75 & $3,381.00$ & 10 & 7 & 124.20 & $8,694.00$ \\
\hline 12 & 625 & 4 & 5 & 120.75 & $2,415.00$ & 10 & 5 & 124.20 & $6,210.00$ \\
\hline 13 & 17,500 & 4 & 10 & 120.75 & $4,830.00$ & 50 & 10 & 124.20 & $62,100.00$ \\
\hline 14 & 2,750 & 4 & 7 & 120.75 & $3,381.00$ & 10 & 7 & 124.20 & $8,694.00$ \\
\hline \multirow[t]{2}{*}{15} & 625 & 4 & 5 & 120.75 & $2,415.00$ & 10 & 5 & 124.20 & $6,210.00$ \\
\hline & 95,625 & 52 & 103 & Sub Total 1 & $43,228.50$ & 310 & 103 & Sub Total 2 & $326,646.00$ \\
\hline \multicolumn{9}{|c|}{ b $(1+2)$ USD } & $369,874.50$ \\
\hline
\end{tabular}

Table 2. The results of the calculation of the existing excavation work 
Table 3. Results of the calculation of alternative excavation jobs

\begin{tabular}{|c|c|c|c|c|c|c|c|c|c|}
\hline \multirow[b]{2}{*}{ Stage } & \multirow{2}{*}{$\begin{array}{c}\text { VOL/ } \\
\text { M3 }\end{array}$} & \multicolumn{4}{|c|}{ EXCAVATOR( EXC ) } & \multicolumn{4}{|c|}{ DUMP TRUCK ( DT ) } \\
\hline & & EXC & Days & $\begin{array}{c}\text { Rental/Days } \\
\text { (USD) }\end{array}$ & $\begin{array}{c}\text { Rental Exc } \\
\text { (USD) }\end{array}$ & DT & Days & $\begin{array}{c}\text { Rental/Days } \\
\text { (USD) }\end{array}$ & $\begin{array}{c}\text { Rental DT } \\
\text { (USD) }\end{array}$ \\
\hline 1 & 8,750 & 2 & 4 & 120.75 & 966.00 & 24 & 4 & 124.20 & $11,923.20$ \\
\hline 2 & 2,750 & 1 & 7 & 120.75 & 845.25 & 12 & 7 & 124.20 & $10,432.80$ \\
\hline 3 & 625 & 1 & 2 & 120.75 & 241.50 & 12 & 2 & 124.20 & $2,980.80$ \\
\hline 4 & 17,500 & 3 & 13 & 120.75 & $4,709.25$ & 35 & 13 & 124.20 & $56,511.00$ \\
\hline 5 & 2,750 & 1 & 7 & 120.75 & 845.25 & 12 & 7 & 124.20 & $10,432.80$ \\
\hline 6 & 625 & 1 & 2 & 120.75 & 241.50 & 12 & 2 & 124.20 & $2,980.80$ \\
\hline 7 & 17,500 & 3 & 13 & 120.75 & $4,709.25$ & 35 & 13 & 124.20 & $56,511.00$ \\
\hline 8 & 2,750 & 1 & 7 & 120.75 & 845.25 & 12 & 7 & 124.20 & $10,432.80$ \\
\hline 9 & 625 & 1 & 2 & 120.75 & 241.50 & 12 & 2 & 124.20 & $2,980.80$ \\
\hline 10 & 17,500 & 3 & 13 & 120.75 & $4,709.25$ & 35 & 13 & 124.20 & $56,511.00$ \\
\hline 11 & 2,750 & 1 & 7 & 120.75 & 845.25 & 12 & 7 & 124.20 & $10,432.80$ \\
\hline 12 & 625 & 1 & 2 & 120.75 & 241.50 & 12 & 2 & 124.20 & $2,980.80$ \\
\hline 13 & 17,500 & 3 & 13 & 120.75 & $4,709.25$ & 35 & 13 & 124.20 & $56,511.00$ \\
\hline 14 & 2,750 & 1 & 7 & 120.75 & 845.25 & 12 & 7 & 124.20 & $10,432.80$ \\
\hline \multirow[t]{2}{*}{15} & 625 & 1 & 2 & 120.75 & 241.50 & 12 & 2 & 124.20 & $2,980.80$ \\
\hline & 95,625 & 24 & 100 & Sub Total 1 & $25,236.75$ & 284 & 100 & Sub Total 2 & $305,035.20$ \\
\hline \multicolumn{9}{|c|}{ Total (Sub $1+$ Sub 2) USD } & $330,271.95$ \\
\hline \multicolumn{9}{|c|}{ Total Efficiency (USD) } & $39,602.55$ \\
\hline \multicolumn{9}{|c|}{$\%$ Savings } & $10,71 \%$ \\
\hline
\end{tabular}

Table 4. Results of the calculation of time efficiency

\begin{tabular}{|c|c|c|c|c|c|c|c|}
\hline \multicolumn{8}{|c|}{ TIME EFFICIENCY ( BORED PILE / SECANT PILE) } \\
\hline \multirow[b]{2}{*}{ No } & \multirow{2}{*}{\multicolumn{2}{|c|}{ Work Item }} & \multirow{3}{*}{$\begin{array}{c}\% \\
3.53\end{array}$} & \multirow{3}{*}{$\begin{array}{c}\text { Total } \\
287,738.28\end{array}$} & \multicolumn{3}{|c|}{ Time } \\
\hline & & & & & \multirow{2}{*}{$\begin{array}{c}\begin{array}{c}\text { Before } \\
\text { (days) }\end{array} \\
301\end{array}$} & \multirow{2}{*}{$\begin{array}{c}\begin{array}{c}\text { After } \\
\text { ( days ) }\end{array} \\
263\end{array}$} & $\begin{array}{c}\text { Deviation } \\
\text { (days ) }\end{array}$ \\
\hline A & 1. Preliminaries & 1.1 Preliminary & & & & & 38 \\
\hline B & & & & arables & & & \\
\hline \multirow{7}{*}{$\mathrm{C}$} & \multicolumn{7}{|c|}{ 3. Piling Work } \\
\hline & \multirow{6}{*}{$\begin{array}{l}3.1 \text { Test Pile \& } \\
\text { Bore Pile }\end{array}$} & 3.1.1 Bored Piling & 16.09 & $1,309,884.96$ & 266 & 233 & 33 \\
\hline & & 3.1.2 Concrete & 20.13 & $1,638,740.34$ & 266 & 233 & 33 \\
\hline & & 3.1.3 Reinforcement & 14.14 & $1,150,871.70$ & 259 & 227 & 32 \\
\hline & & 3.1.4 Testing & 2.07 & $168,457.98$ & 280 & 245 & 35 \\
\hline & & 3.1.5 Sundries & 2.31 & $188,243.04$ & 301 & 263 & 38 \\
\hline & & 3.1.6 Others & 4.73 & $385,279.44$ & 287 & 251 & 36 \\
\hline \multirow{6}{*}{$\mathrm{D}$} & \multicolumn{7}{|c|}{ 4. Retention System } \\
\hline & \multirow{5}{*}{ 4.1 Secant Pile } & 4.1.1 Bored Piling & 13.35 & $1,087,119.84$ & 287 & 251 & 36 \\
\hline & & 4.1.2 Concrete & 10.16 & $826,820.10$ & 175 & 153 & 22 \\
\hline & & 4.1.3 Reinforcement & 13.38 & $1,089,562.44$ & 175 & 153 & 22 \\
\hline & & 4.1.4 Sundries & & & & & \\
\hline & & 4.1.5 Others & 0.11 & $9,281.88$ & 161 & 141 & 20 \\
\hline \multicolumn{3}{|c|}{ Contract Value } & 100 & $8,142,000.00$ & 251 & 219 & 31 \\
\hline \multicolumn{7}{|c|}{ \% Efficiency } & $12.51 \%$ \\
\hline
\end{tabular}


Table 5. Cost Efficiency Calculation Results

\begin{tabular}{|c|c|c|c|c|c|c|c|c|}
\hline \multicolumn{9}{|c|}{ COST EFFICIENCY (BORED PILE / SECANT PILE) } \\
\hline \multirow[b]{2}{*}{ No } & \multirow{2}{*}{\multicolumn{3}{|c|}{ Work Item }} & & \multirow[b]{2}{*}{ Total } & \multicolumn{3}{|c|}{ Cost } \\
\hline & & & & & & \multirow{2}{*}{$\begin{array}{c}\begin{array}{c}\text { Before } \\
\text { (USD) }\end{array} \\
287,738.28\end{array}$} & \multirow{2}{*}{$\begin{array}{c}\begin{array}{c}\text { After } \\
\text { (USD) }\end{array} \\
251,837.18\end{array}$} & \multirow{2}{*}{$\begin{array}{c}\begin{array}{c}\text { Deviation } \\
\text { (USD) }\end{array} \\
35,901.10\end{array}$} \\
\hline A & \multicolumn{2}{|c|}{ 1. Preliminaries } & \multicolumn{2}{|c|}{ 1.1 Preliminary } & $287,738.28$ & & & \\
\hline B & \multicolumn{8}{|c|}{ 2. Parables } \\
\hline$D$ & \multicolumn{8}{|c|}{ 3. Piling Work } \\
\hline \multirow{6}{*}{$\mathrm{C}$} & \multirow{6}{*}{$\begin{array}{l}\text { 3.1.Test } \\
\text { Pile \& } \\
\text { Bore Pile }\end{array}$} & \multicolumn{2}{|c|}{ 3.1.1 Bored Piling } & 16.09 & $1,309,884.96$ & $1,309,884.96$ & $1,146,450.65$ & $163,434.31$ \\
\hline & & \multicolumn{2}{|c|}{ 3.1.2 Concrete } & 20.13 & $1,638,740.34$ & $1,638,740.34$ & $1,638,740.34$ & 0.00 \\
\hline & & \multicolumn{2}{|c|}{ 3.1.3 Reinforcement } & 14.14 & $1,150,871.70$ & $1,150,871.70$ & $1,150,871.70$ & 0.00 \\
\hline & & \multicolumn{2}{|c|}{ 3.1.4 Testing } & 2.07 & $168,457.98$ & $168,457.98$ & $168,457.98$ & 0.00 \\
\hline & & \multicolumn{2}{|c|}{ 3.1.5 Sundries } & 2.31 & $188,243.04$ & $188,243.04$ & $164,755.96$ & $23,487.08$ \\
\hline & & \multicolumn{2}{|c|}{ 3.1.6 Others } & 4.73 & $385,279.44$ & $385,279.44$ & $337,208.13$ & $48,071.31$ \\
\hline $\mathrm{D}$ & \multicolumn{5}{|c|}{ 4. Retention System } & & & \\
\hline & \multirow{5}{*}{$\begin{array}{l}\text { 4.1 Secant } \\
\text { Pile }\end{array}$} & \multicolumn{2}{|c|}{ 4.1.1 Bored Piling } & 13.35 & $1,087,119.84$ & $1,087,119.84$ & $951,479.92$ & $135,639.92$ \\
\hline & & & 2 Concrete & 10.16 & $826,820.10$ & $826,820.10$ & $826,820.10$ & 0.00 \\
\hline & & & einforcement & 13.38 & $1,089,562.44$ & $1,089,562.44$ & $953,617.76$ & $135,944.68$ \\
\hline & & & 4 Sundries & & & & & \\
\hline & & & .5 Others & 0.11 & $9,281.88$ & $9,281.88$ & $8,123.78$ & $1,158.10$ \\
\hline & Contr: & $\mathrm{t}$ Val & & 100 & $8,142,000.00$ & $8,142,000.00$ & $7,598,363.51$ & $543,636.49$ \\
\hline & & & & & iciency & & & $6.68 \%$ \\
\hline
\end{tabular}

Table 6. Total Time -Efficiency Calculation Results

\begin{tabular}{|c|c|c|c|c|c|}
\hline \multirow{2}{*}{ No. } & \multirow{2}{*}{ Work Item } & \multicolumn{2}{|c|}{ Duration } & \multirow{2}{*}{ Efficiency } & \multirow{2}{*}{ After } \\
\cline { 2 - 5 } & & Before & 219 & 31 & 12.51 \\
\hline 1 & Bored Pile, Secant Pile & 251 & 100 & 3 & 2.91 \\
\hline 2 & Excavation & 103 & 319 & 34 & 9.60 \\
\hline
\end{tabular}

Table 7. Total Cost-Efficiency Calculation Results

\begin{tabular}{|c|c|c|c|c|c|}
\hline \multirow{2}{*}{ No. } & \multirow{2}{*}{ Work Item } & \multicolumn{2}{|c|}{ Duration } & \multirow{2}{*}{ Efficiency } & \multirow{2}{*}{$\%$} \\
\cline { 3 - 5 } & & Before & After & & \\
\hline 1 & Bored Pile, Secant Pile & $8,142,000$ & $7,598,363.51$ & $543,636.49$ & $6.68 \%$ \\
\hline 2 & Excavation & $369,874.5$ & $330,271.95$ & $39,602.55$ & $10,71 \%$ \\
\hline & Total & $8,511,875$ & $7,928,635$ & 583,289 & $6,85 \%$ \\
\hline
\end{tabular}

d) Improve

The improvements that will be made in this research are :

Table 8. The improved stage of the research

\begin{tabular}{|c|c|c|c|}
\hline No & Factor & Problem & Solution \\
\hline 1 & Desain & $\begin{array}{c}\text { Bad Design and } \\
\text { Delay Design }\end{array}$ & $\begin{array}{c}\text { Team Work and } \\
\text { Coordinator }\end{array}$ \\
\hline 2 & Planning & $\begin{array}{c}\text { Inadequate } \\
\text { Planning and } \\
\text { Scheduling }\end{array}$ & $\begin{array}{c}\text { Team Work and } \\
\text { Coordinator }\end{array}$ \\
\hline 3 & Implementation & $\begin{array}{c}\text { Error During } \\
\text { Construction }\end{array}$ & $\begin{array}{c}\text { Team Work and } \\
\text { Coordinator }\end{array}$ \\
\hline
\end{tabular}

\section{e) Control}

The control stage is carried out by the coordinator of each division to reduce or erase errors in construction implementation. Control work is carried out regularly and in an organized manner.

\section{Conclusions}

From the research results it can be concluded as follows:

1. Analyzing lean six sigma is done by using 5 stages, namely define, measure, analyze, improve and control. 
2. It can be seen that the total cost efficiency for drilling pile work, cutting piles is $6.68 \%$, and excavation is $10.71 \%$ so that the total cost efficiency is $6.85 \%$.

3. It can be seen that the total time efficiency for drilling pile work, cutting piles is $12.51 \%$, and excavation is $2.91 \%$ so that if you add it the time efficiency becomes $9.60 \%$.

\section{REFERENCES}

[1] Husin, A. E., \& Priyanto, D. (2018). Lean Construction Based Tower Crane Requirement Optimization In High Rise Building Construction Project. International Journal of Scientific Research Engineering \& Technology (IJSRET), 7(10), 738-743.

[2] Hassan, H., Mangare, J. B., \& Pratasis, P. A. K. (2016). Faktor-faktor penyebab keterlambatan pada proyek konstruksi dan alternatif penyelesaiannya (studi kasus : di manado town square III). Jurnal Sipil Statik Vol.4.

[3] Gaspersz, J. (2011). Compete with Creativity. SSRN Electronic Journal, 1-17. https://doi.org/10.2139/ssrn.983934

[4] Kamaruddeen, A. M., Sung, C. F., \& Wahi, W. (2020). A study on factors causing cost overrun of construction projects in Sarawak, Malaysia. Civil Engineering and Architecture, 8(3), 191-199. https://doi.org/10.13189/cea.2020.080301

[5] Husin, A. E. (2019). Application of PERT and Six Sigma integration on building pile foundation. International Journal of Civil Engineering and Technology.

[6] International Labour Organization. (2013). Global employment trends 2013. In Global Employment Trends.

[7] Chan, A. P. C., Scott, D., \& Chan, A. P. L. (2004). Factors Affecting the Success of a Construction Project. Journal of Construction Engineering and Management. https://doi.org/10.1061/(ASCE)0733-9364(2004)130:1(15 3)

[8] Gaspersz, 2011. (n.d.).

[9] Tjahjono, B., Ball, P., Vitanov, V. I., Scorzafave, C.,
Nogueira, J., Calleja, J., Minguet, M., Narasimha, L., Rivas, A., Srivastava, A., Srivastava, S., \& Yadav, A. (2010). Six sigma: A literature review. International Journal of Lean Six Sigma. https://doi.org/10.1108/20401461011075017

[10] Gaspersz, 2007. (n.d.).

[11] Evans, J. R., \& Lindsay, W. M. (2008). The Management and Control of Quality. The Management and Control of Quality.

[12] Koskela, L., \& Howell, G. (2002). The theory of project management: Explanation to novel methods. Proceedings 10th Annual Conference on Lean Construction.

[13] Husin, A. E., Fahmi, F., Rahardjo, S., Siregar, I. P., \& Kussumardianadewi, B. D. (2019). M-PERT and lean construction integration on steel construction work of warehouse buildings. International Journal of Engineering and Advanced Technology, 8(4), 696-702. https://doi.org/10.13140/RG.2.2.19873.66402

[14] Ohno, T. (1988). Toyota Production System Summary. In Toyota Production System: Beyond Large-Scale Production

[15] Hardiyatmo, H. C. (2006). Mekanika Tanah II Edisi 3. In Gadjah Mada University Press.

[16] Anderson, S. (2012). Types of retaining walls. ICE Manual of Geotechnical Engineering Volume 2: Geotechnical Design, Construction, and Verification.

[17] Galler, R. (2017). Excavation. In Rock Mechanics and Engineering Volume 4: Excavation, Support, and Monitoring. https://doi.org/10.1201/b20406

[18] Peurifoy, R. L., Ledbetter, W. B., \& Schexnayder, C. J. (1996). Construction planning, equipment, and methods. In McGraw-Hill series in construction engineering and project management.

[19] Irdayani, I., \& Hardjomuljadi, S. (2017). KENDALA PROYEK KONSTRUKSI YANG DIKERJAKAN SECARA SWAKELOLA DI KABUPATEN PINRANG. Konstruksia. https://doi.org/10.24853/jk.8.1.61-73

[20] Samarghandi, H., Tabatabaei, S. M. M., Taabayan, P., Hashemi, A. M., \& Willoughby, K. (2016). Studying the reasons for delay and cost overrun in construction projects: The case of Iran. Journal of Construction in Developing Countries. https://doi.org/10.21315/jcdc2016.21.1.4 